\title{
A relação filosofia-teologia na América Latina
}

\author{
The relationship between philosophy and theology in Latin America
}

\author{
Francisco de Aquino Júnior*
}

\begin{abstract}
Resumo
O artigo trata da problemática da relação teologia-filosofia nas teologias da libertação ou da mediação filosófica dessas teologias. É um tema não estudado ou mesmo silenciado. Praticamente não existe estudo sobre isso. No máximo, alguma referência ou algum comentário sobre a influência de um filósofo ou de uma filosofia em alguma teologia da libertação concreta. O que já é um bom indicativo da (não) importância ou do lugar (periférico) da mediação filosófica nessas teologias. O texto começa mostrando como, com raríssimas exceções, essa problemática ou não foi tematizada e desenvolvida ou foi apenas indicada e/ou esboçada nas teologias da libertação (aproximação historiográfica). Num segundo momento, indica, sem maiores desenvolvimentos, a importância e o lugar da mediação filosófica, bem como sua necessidade e sua contribuição para o quefazer e para o produto dessas teologias (aproximação sistemática). Não se pretende, aqui, desenvolver nem sequer esboçar uma mediação filosófica concreta para as teologias da libertação, mas simplesmente problematizar a questão em seu desenvolvimento histórico e em sua estrutura teórica fundamental e, com isso, colocar a necessidade e o desafio de desenvolvimento dessa mediação como uma mediação importante e necessária no processo global de inteligência da fé.
\end{abstract}

Palavras-chave: Filosofias; Teologias da libertação; Inteligência; Razão; Mediação filosófica.

\begin{abstract}
This article deals with the relationship between theology and philosophy, the theologies of liberation, or rather, the philosophical mediation of these theologies. This theme has not been studied or even silenced. There is practically no study on it. At most, there is some reference or comment about the influence of a philosopher or philosophy on some concrete liberation theology. This is already a good indication of the non-importance or the (peripheral) place of philosophical mediation in these theologies. This article begins by showing how, with very few exceptions, this subject has either not been thematized an developed, or it was only indicated and/or outlined in liberation theologies (historiographical approach). Secondly, this paper indicates, without further development, the importance and place of philosophical mediation, as well as its necessity and contribution to what to do, and how to contribute to the product of these theologies (systematic approach). It is not intended here to develop or even to outline a concrete philosophical mediation for the theologies of liberation. We simply want to problematize the issue in its historical and in its fundamental theoretical structure. From this we intend to place the need and the challenge of developing this important and necessary mediation in the global process of the intelligence of the faith.
\end{abstract}

Keywords: Philosophers; Liberation; Theologies; Intelligence; Reason; Philosophical mediation.

Artigo recebido em 09 de outubro de 2016 e aprovado em 20 de dezembro de 2016.

* Doutor em Teologia na Westfälischen Wilhelms - Universität de Münster - Alemanha; Licenciado em filosofia na Universidade Estadual do Ceará; Presbítero da Diocese de Limoeiro do Norte - CE e Professor de teologia na Faculdade Católica de Fortaleza (FCF) e na Universidade Católica de Pernambuco (UNICAP). País de origem: Brasil. E-mail: axejun@yahoo.com.br 


\section{Introdução}

A problemática da relação filosofia e teologia na América Latina é algo bastante complexo e ambíguo, a começar pela diversidade de teologias existentes ou feitas em nosso Continente: teologias tradicional-escolásticas, teologias moderno-europeias, teologias de tradição protestante, teologias carismáticopentecostais, teologias da libertação etc. E em cada uma dessas teologias, a questão da relação filosofia-teologia tem características muito peculiares. Não vamos tratar aqui de todas essas teologias presentes no Continente, mas apenas das teologias da libertação que se pretendem explicitamente latino-americanas e que, por isso mesmo, serão nomeadas ou indicadas indistintamente em termos de teologias da libertação ou teologias latino-americanas.

É preciso reconhecer antes de tudo que a problemática da relação filosofiateologia não teve nas teologias da libertação a mesma importância e centralidade que teve no conjunto da tradição teológica ocidental. O que não significa dizer que tenha estado completamente ausente nas produções e nos debates desenvolvidos por essas teologias, embora se trate de uma presença mais implícita (nível dos pressupostos e das implicações teórico-práticos) que explicita (nível da tematização).

Mesmo no âmbito das discussões epistemológicas, onde se problematiza e se reflete o fazer teórico-teológico, algo típico da atitude e do pensar filosóficos, essa problemática não parece ter desempenhado um papel tão central e determinante no conjunto das teologias latino-americanas. Em geral, foi algo mais pressuposto que desenvolvido. Na melhor das hipóteses, com raríssimas exceções, algo apenas indicado ou esboçado. Sem falar que muitas teologias (principalmente as teologias indígenas e negras, mas também as teologias populares), distinguindo ou mesmo opondo o modo de pensar dos povos originários (sapiencial) ao modo de pensar grego (filosófico), entendem-se e desenvolvem-se não tanto segundo o esquema filosofia-teologia, mas, antes, segundo o esquema teologia-sabedoria. Dizemos “não 
tanto, mas, antes" porque esta distinção/oposição (sabedoria X filosofia) não deixa de ser uma atitude ou mesmo um esboço de teoria filosófica.

Tudo isso torna a abordagem de nosso tema bastante complexa e difícil, mas também bastante interessante e oportuna. Começaremos fazendo algumas constatações sobre a relação filosofia-teologia nas teologias da libertação (aproximação historiográfica). E, num segundo momento, faremos uma abordagem mais sistemática da problemática, indicando sua importância, seu lugar e algumas de suas contribuições para o quefazer teológico (aproximação sistemática).

\section{APROXIMAÇÃO HISTORIOGRÁFICA}

Convém começar fazendo um balanço histórico da importância e do lugar da problemática filosofia-teologia no conjunto das teologias da libertação. Falamos de "balanço" e de "conjunto" porque nem vamos analisar exaustivamente a problemática, nem vamos nos deter na análise dessa problemática em nenhuma teologia da libertação concreta, nem muito menos do conjunto das teologias da libertação. Nossa pretensão é muito mais modesta. Queremos simplesmente esboçar um panorama geral do papel desempenhado por essa problemática no fazer teológico latino-americano. Embora correndo o risco de simplificações e/ou generalizações apressadas, esse tipo de abordagem tem a vantagem de oferecer uma visão de conjunto da questão em sua complexidade e em suas ambiguidades e, com isso, explicitar a necessidade e urgência de desenvolver ou ao menos esboçar de modo sistemático a importância e o lugar dessa problemática no conjunto do fazer teológico. É neste sentido bastante amplo que falamos aqui de uma “aproximação historiográfica”.

A problemática da relação filosofia-teologia no conjunto das teologias da libertação é algo bastante complexo e ambíguo, começando pela pluralidade que caracteriza o que de forma um tanto genérica e simplória se convencionou chamar 
“teologia da libertação” (TdL). Na verdade, nunca existiu uma TdL no singular, nem sequer nas primeiras décadas quando se falava normalmente de TdL no singular e quando ainda não tinha se desenvolvido de modo mais ou menos explícito e autônomo uma diversidade de teologias da libertação irredutíveis umas às outras e até mesmo em conflito umas com as outras (teologia feminista, teologia negra, teologia indígena, teologia popular, teologia ecológica, teologia gay etc.).

E essa pluralidade que caracteriza o movimento teológico latino-americano que se convencionou chamar TdL (no singular) e que cada vez mais é nomeado como teologias da libertação (no plural) não diz respeito apenas aos conteúdos abordados, mas também e sobretudo ao modo de abordá-los. O que repercute de maneira determinante na problemática filosofia-teologia no fazer teológico. Não só pela diversidade de filosofias assumidas e/ou pressupostas, mas também pela importância e pelo lugar que essa problemática tem e/ou ocupa no fazer e no produto teológicos.

Grosso modo, não obstante o risco de simplificação e generalização já indicado, podemos afirmar que a problemática filosofia-teologia no conjunto das teologias da libertação, com raríssimas exceções, ou não foi tematizada e desenvolvida ou foi apenas indicada e/ou esboçada. $\mathrm{E}$ isso tem muitas consequências positivas e negativas para as teologias da libertação que convém considerar.

\section{Uma problemática não tematizada nem desenvolvida}

Grande parte da produção teológica latino-americana não se confrontou direta e explicitamente com essa problemática. E por várias razões: ou porque não parecia relevante nem necessário; ou porque seu nível de elaboração não implicava ou até prescindia dessa problemática; ou porque sua forma de elaboração se desenvolvia numa matriz teórica distinta da matriz teórica ocidental. 


\section{A. Irrelevância e/ou ineficácia}

Se é verdade que a filosofia se constituiu na principal interlocutora da teologia ocidental até a primeira metade do século XX; também é verdade que as ciências humanas em geral e as ciências sociais em particular se tornaram as interlocutoras mais importantes da reflexão teológica latino-americana. Há quem pense até que elas chegaram a substituir a filosofia como mediação teórica fundamental no quefazer teológico. Em todo caso, não há como negar o fato dessa interlocução nem sua importância nas teologias latino-americanos (BOFF, 1983, p. 35-119; GUTIÉRREZ, 2000a, p. 67-97; LIBANIO, 1987, p. 173-207; ANDRADE, 1991; AQUINO JÚNIOR, 2012, p. 1337-1367).

Embora não seja uma consequência necessária, tal fato não deixa de estar ligado ao dinamismo teológico-pastoral desencadeado pelo Concílio Vaticano II e radicalizado pela Igreja latino-americana a partir das Conferências de Medellín e Puebla e da teologia da libertação. Se a Igreja se entende como "sacramento de salvação" ou como "sinal e instrumento do Reino" no "mundo" ( $L G 1,5,8,9,48$; $G S$ 42, 45; $A D$ 1, 5 ; $S C$ 5s) e se essa "salvação" em contextos de miséria e opressão se realiza como "libertação" (Medellín, Introdução), a referência ao mundo e aos processos de libertação aparece como algo constitutivo da Igreja e sua missão salvífica. E, assim, o conhecimento do mundo, particularmente no que tem de opressão-libertação, torna-se algo fundamental para a vivência da fé e para a missão da Igreja.

Neste contexto, as ciências que se dedicam ao conhecimento do mundo, de modo especial as ciências humanas em geral e a ciências sociais em particular, adquirem uma importância enorme na vivência da fé e na realização da missão da Igreja e, consequentemente, na reflexão teológica, enquanto inteligência da fé. Frente a essas ciências que nos ajudam a conhecer o mundo tal como ele se apresenta, bem como as reais possibilidades de transformação das injustiças sociais, a filosofia (filosofia clássica? Filosofia escolástica? qualquer filosofia?) 
aparece, não raras vezes, como abstração e/ou especulação pouco eficaz ou, em todo caso, como algo secundário. Não se trata tanto de uma negação explícita e radical da mediação filosófica no fazer teológico, mas, antes, de um preterir, de um não priorizar ou simplesmente de um deixar de lado. Mesmo quando se reconhece explicitamente a importância da mediação filosófica no fazer teológico, isso não recebe maiores desenvolvimentos nem muito menos um tratamento adequado (GUTIÉRREZ, 2000, p. 65s; ANDRADE, 1991, p. 162-169; BOFF, 1998, p. 371385). Com raríssimas exceções, esta posição está bastante presente no conjunto das teologias da libertação, ainda que de forma mais ou menos inconsciente e/ou implícita e radical.

\section{Clodovis Boff formulou bem a questão:}

No currículo canônico, o estudo orgânico da filosofia é até hoje apresentado e exigido como a grande mediação teórica da teologia e não as ciências humanas, incluindo as sociais. Contudo, poder-se-ia levantar a seguinte questão: No contexto do terceiro mundo, será ainda a filosofia a mediação privilegiada da teologia? De fato, as grandes questões que desafiam a Igreja na Periferia do mundo não dizem diretamente respeito à ordem do ser, mas sim à ordem do viver. Não são as questões meta-físicas, mas cruamente questões físicas. São as que se referem às chamadas 'necessidades básicas' tais como: trabalho, comida, moradia, educação e saúde básicas [...]. Para as imensas maiorias do planeta, a questão mais premente não é a das 'razões de viver' [...]. A questão mais urgente é, sim, a dos 'meios de viver'. Ora, para enfrentar as dramáticas questões sociais das grandes massas, a Igreja necessita da ajuda das ciências sociais [...]. Efetivamente, as ciências, mais que a filosofia, educam para a análise, para além da reflexão pura; para o lado concreto, isto é, positivo e experimental das questões e não para o seu lado abstrato; para os aspecto prático, e não para as discussões puramente teóricas e, muitas vezes, inconcludentes [...]. Se assim é, a filosofia [...] já não parece mais gozar do estatuto de interlocutora principal da teologia. Esse papel competiria hoje às ciências humanas e sociais (BOFF, 1998, p. 379ss). ${ }^{1}$

\footnotetext{
${ }^{1}$ Boff adverte que "não se trata aqui de substituir um interlocutor por outro. Pois ambas, filosofia e ciências, são necessárias para a teologia. A pergunta versa apenas sobre a questão do interlocutor principal ou privilegiado, ou seja, pela mediação cultural mais urgente" (BOFF, 1998, p. 381).
} 


\section{B. Nível de elaboração}

Além de privilegiar a mediação das ciências humanas em vista de um maior conhecimento da realidade e de seus processos de transformação, as teologias da libertação nasceram e se desenvolveram numa relação muito estreita com as comunidades eclesiais de base e sua ação pastoral/evangelizadora. E isso determinou em boa medida o tipo de teologia que foi sendo produzida na América Latina: tanto no que diz respeito ao conteúdo (questões, urgências, prioridades etc.), quanto no que diz respeito ao nível de elaboração (sensibilidade, linguagem, perguntas etc.).

Clodovis Boff distinguiu na teologia latino-americana três "formas de discurso" quanto ao "nível de elaboração teórica": Teologia profissional que "adota em geral o caminho da ciência" (lógica da ciência); Teologia pastoral "próxima do gênero sabedoria" (lógica da ação); Teologia popular que "corresponde ao 'senso comum' e tem a forma da linguagem ordinária” (lógica do cotidiano). (BOFF, 1998, p. 597-608).

E Juan Luis Segundo, em uma conferência intitulada "Críticas e autocríticas da Teologia da Libertação", tratando de questões epistemológicas dessa teologia, mais concretamente da relação teologia da libertação e prática pastoral, afirma que

a maior parte da produção da teologia da libertação, a mais criativa pedagógica e teologicamente falando, não está direcionada atualmente ao nível acadêmico de costume nem mesmo a um público culto médio como acontece em outras partes, mas a acompanhar e a ajudar à reflexão que se faz precisamente dentro das comunidades eclesiais de base. Existe ai uma quantidade enorme de material teológico que se está criando continuamente na América Latina, material vulgarizado no âmbito popular, simplificado em seus termos e em suas temáticas, mas afinal teológico. E muitas vezes original e valioso (SEGUNDO, 1993, p. 215-236).

Deixando de lado a crítica desenvolvida por Segundo no sentido de que a teologia da libertação foi, com isso, senão suprimindo, tomando para si a função mediadora da pastoral e, assim, constituindo-se como uma teologia pastoral, isto é, 
como uma teologia que "surge já na forma direta da fé feita práxis no povo cristão", uma teologia que "se faz escutando o povo e em diálogo com ele" (SEGUNDO, 1993, p. 228), importa reconhecer que neste nível de elaboração teórica, a filosofia aparece não apenas como algo secundário e/ou ineficaz, mas também como algo estranho. E pouco importa, aqui, se essa estranheza pode ser compreendida e formulada apenas em termos de "níveis de elaboração teórica” (primário/básico secundário/posterior) ou se, em última instância, não deve ser compreendida e formulada em termos de "formas de elaboração teórica” (sapiencial/concreto X filosófico/abstrato).

Fato é que boa parte da produção teológica latino-americana foi desenvolvida, para usar a formulação de Clodovis Boff, segundo a lógica da vida cotidiana e da ação (sabedoria) e não segundo a lógica da ciência e da filosofia (teoria). É uma teologia muito mais ligada ao concreto, às experiências, aos sentidos...; pouco afeita ou mesmo um tanto avessa às especulações e abstrações próprias do pensar filosófico. Mais que uma questão de irrelevância ou ineficácia, a não tematização ou o não desenvolvimento da problemática filosofia-teologia tem a ver, aqui, com uma diversidade de "níveis" ou mesmo de "formas" de elaboração teológica.

\section{Forma de elaboração}

Algumas teologias da libertação - principalmente as teologias indígenas e negras, mas também as teologias populares - têm chamado atenção para sua forma própria de inteligência da fé. Ela não pode ser reduzida a uma espécie de popularização/vulgarização da teologia a ser desenvolvida posteriormente ou que pressupõe uma teologia mais desenvolvida (nível de elaboração teórica). É, antes e mais radicalmente, uma maneira diferente de fazer teologia (forma de elaboração), ligada à uma matriz cultural distinta da matriz ocidental - "matriz" no sentido genuíno de "útero" ou "seio materno" onde a vida é gestada e se desenvolve, 
também no que diz respeito ao modo de intelecção (apreensão e expressão) da realidade.

Trata-se, aqui, de uma forma simbólico-sapiencial de fazer teologia (mais ligada ao concreto, ao cotidiano, às experiências etc.), diferente da forma teóricoconceitual da teologia ocidental que predomina inclusive na maioria das teologias da libertação (mais abstrata, especulativa, objetiva, precisa etc.). É uma forma de fazer teologia que se dá, sobretudo, através de mitos, estórias, arte, liturgia, exercícios de piedade etc. e em linguagem narrativa, sapiencial, simbólica etc. (IRARRAZAVAL, 1993, p. 181-197; 2007, p. 103-113). E, aliás, uma forma de teologia muito mais próxima do modo bíblico de fazer teologia (ZIMMERMANN, 1988, p. 204-210; ZIENER, 1988, p. 794-798; CORBAN - VANHOYE, 1972, p. 165169; BOFF, 1998, p. 188-192).

Víctor Codina, de modo especial, tem insistido muito, ainda que numa formulação um tanto ambígua, na novidade e na irredutibilidade do que chama "razão simbólica" em relação à "razão ocidental" e mais precisamente à "razão moderna":

Frente ao mundo da razão lógica instrumental e matemática, a razão simbólica enfatiza o mundo do coração, da vivência, da experiência, da religião, com seus símbolos e ritos. Não se preocupa somente com os meios ou instrumentos, e sim com os fins, com o para quê e para onde. Diante do mundo ocidental, tão machista, inclui a perspectiva da mulher, mais intuitiva e profunda. Diante da consideração absolutizante da história e do progresso, realça a importância da natureza, do cosmos, da terra, como sacramento religioso. Diante do mundo da violência, busca a utopia da não violência, pois a razão simbólica é vital e está apegada às fontes da vida. Diante da eficácia da práxis, privilegia a festa, e diante do serviço, propicia a comunhão: não somente ser para os demais (Bonhoeffer), mas sim, estar com os demais, participar, compartilhar. Diante da universalidade do racional e do técnico, que busca uma língua universal, comum e planetária (inglês, esperanto...), valoriza o pluralismo, o nacional, a pátria, a família, a casa, as línguas, as culturas, a memória, o relato... Diante da acentuação unilateral da ética, sublinha a estética, o formoso e o belo. Não somente uti (usar, o útil...) e sim frui (desfrutar, gozar...). (CODINA, 1997, p. 176s). 
O próprio Codina reconhece que não é fácil caracterizar nem definir essa "razão simbólica", pois ela "pertence ao âmbito supralógico: o cordial, o imaginativo, o vital, o mítico, o poético... e enlaça as raízes últimas do ser humano e do povo” (CODINA, 1997, p. 175), e que sua afirmação não significa uma negação sem mais da "razão ocidental” (CODINA, 1997, p. 174s; 1999, p. 185-189). Mas insiste que "não se pode universalizar o conceito ocidental de 'teologia”, pois há “outras expressões não escritas nem racionais de teologia que expressam a experiência de Deus através de mitos, lendas, hinos, cantos, ritos, símbolos que são comunicados oralmente de geração em geração". De modo que "identificar a teologia com a teologia ocidental greco-latina ou europeia é empobrecer o sentido da teologia" (CODINA, 2010, p. 193s).

Importa reconhecer, em todo caso, que, para algumas teologias da libertação, a não tematização da problemática filosofia-teologia não significa um problema nem um desafio, mas, antes, indica uma forma diferente de fazer teologia. Frente ao modo teórico-conceitual de fazer teologia no Ocidente, temos, aqui, um modo simbólico-sapiencial de fazer teologia, próprio dos povos originários. Se a relação filosofia-teologia é fundamental na teologia ocidental; nas teologias indígena-negra-popular, a relação decisiva é teologia-sabedoria.

\section{Uma problemática apenas intuída e/ou esboçada}

Se é verdade que grande parte da produção teológica latino-americana não se confrontou direta e explicitamente com a problemática da relação filosofiateologia; também é verdade que essa problemática não esteve completamente ausente, sobretudo nas primeiras décadas e em suas primeiras elaborações - até por influência da teologia europeia em que foram formadas as primeiras gerações de teólogos da libertação. Em todo caso, em geral, foi apenas intuída, indicada e/ou esboçada. Exceção, aqui, é, sem dúvida nenhuma, Ignacio Ellacuria e, em parte, Juan Carlos Scannone. 
Embora não tenhamos condição de desenvolver um estudo abrangente nem muito menos exaustivo dessa problemática nas teologias da libertação, vamos pelo menos recolher suas principais intuições, indicações e esboços e (arriscar!?) indicar suas perspectivas e/ou orientações fundamentais.

\section{A. Intuições, indicações, esboços...}

Mesmo sem maiores desenvolvimentos e prescindindo da discussão de suas reais implicações no fazer teológico, podemos encontrar em alguns escritos de teologia da libertação intuições, indicações e esboços da problemática filosofiateologia:

a) Gustavo Gutiérrez, falando da teologia da libertação como "reflexão crítica da práxis histórica à luz da Palavra" (GUTIÉRREZ, 2000, p. 71), indica uma série de fatores de ordem científica e filosófica e de ordem estritamente teológica que contribuíram para destacar o caráter práxico do fazer teológico. Com relação aos fatores de ordem filosófica, destaca a "importância da ação humana como ponto de partida de toda reflexão". E se refere explicitamente a Blondel e sua concepção do quefazer filosófico como "reflexão crítica da ação" e a "influencia do pensamento marxista centrado na práxis, voltado para a transformação da sociedade" (GUTIÉRREZ, 2000, p. 65s). O grande desafio, aqui, consiste em "colocar o trabalho teológico no complexo e fecundo contexto da relação teoria-práxis" (GUTIÉRREZ, 1981, 293; 200ob, p. 107-104).

b) Juan Luis Segundo, mais que de teologia da libertação, fala de "libertação da teologia" (SEGUNDO, 1978). Para ele, "a libertação não pertence tanto ao conteúdo quanto ao método que se usa para fazer teologia frente à nossa realidade" (SEGUNDO, 1978, p. 11). E esse método consiste fundamentalmente no que ele chama "círculo hermenêutico", isto é, "a contínua mudança de nossa interpretação da Bíblia em função das contínuas mudanças de nossa realidade presente, tanto individual quanto social" (SEGUNDO, 1978, p. 10). Ele reconhece explicitamente a 
influência de filosofias existencialistas e hermenêuticas em seu pensamento: leu bastante Sartre, Marcel, Heidegger e outros existencialistas; com 23 anos publicou seu primeiro livro: Existencialismo, filosofia e poesia: ensaio de síntese; e as duas teses que escreveu para o doutorado em teologia estão dedicadas respectivamente ao estudo do existencialista russo Berdiaeff (tese central) e de Paul Ricoeur (tese complementar). (CORONADO, 1998, p. 19-23).

c) Clodovis Boff, em sua tese de doutorado sobre a Teologia do político e suas mediações desenvolveu bastante questões de epistemologia na linha Ladrière, Althusser, Bachelard, Bourdieu e Ricoeur (BOFF, 1983, p. 30), mas não propriamente a mediação filosófica. Em Teoria do Método Teológico, trata explicitamente da mediação filosófica da teologia mais como "postura filosófica" que como "sistema filosófico" (BOFF, 1998, p. 374). Em todo caso, pode-se identificar tanto na tese de doutorado quanto em seus escritos posteriores uma dupla e tensa influência, cuja predominância varia bastante em épocas e em textos: filosofia clássico-escolástica (em especial Aristóteles e Tomás de Aquino) e filosofias hermenêuticas. E cada vez mais o pêndulo pende para a filosofia clássicoescolástica (BOFF, 2008, p. 918s; 2015, p. 1559-1579).

d) Ignacio Ellacuría foi certamente o teólogo que de modo mais sistemático e consequente desenvolveu a mediação filosófica de seu fazer teológico em diálogo fecundo e criativo com a filosofia de Xavier Zubiri (ELLACURIA, 2000a, p. 187218; 2000b, p. 219-234; 2000e, p. 235-245; 2000f, p. 271-301; 1996; 1999a; 2001; 2009; 1999b). Em seus arquivos, encontra-se, aliás, um esquema de curso ou conferência de 1985, onde indica dois aportes fundamentais da filosofia zubiriana à TdL: "Na ordem epistemológica, as teses fundamentais de Zubiri dão razão ao método da TdL e o potenciam" (congenereidade de realidade e inteligência, superação da "logificação da inteligência" pela "inteligização do logos", caráter sentiente da inteligência, inteligência como momento da práxis); "na ordem metafísica, os aportes de Zubiri fundamentam discursos básicos da TdL" (caráter estrutural-dinâmico da realidade, importância metafísica do histórico, importância 
teologal da história, o phylum humano como sujeito da história, a materialidade da história não permite evasões idealistas ou transcendentalistas”) (ELLACURIA, $1985)^{2}$.

e) Juan Carlos Scannone, vinculado à teologia da libertação desenvolvida na Argentina e conhecida como teologia popular ou teologia do povo ou teologia populista (SCANNONE, 1976; 1993, p. 321-346; AQUINO JÚNIOR, 2010, p. 5969), mais que um teólogo da libertação, considera-se um filósofo a serviço dessa teologia (SCANNONE, 1989, p. 78). Ele trata a TdL como uma hermenêutica da práxis dos povos latino-americanos compreendida numa perspectiva "históricocultural" (SCANNONE, 1993, p. 336) a partir da categoria teórico-simbólica mestiçagem cultural da qual deriva a categoria povo latino-americano (SCANNONE, 1990, p. 147ss). E desenvolve uma fundamentação filosófica dessa teologia em diálogo fecundo com as tradições hermenêuticas, particularmente com Paul Ricoeur (SCANNONE, 1990, p. 140-146) na linha de uma "filosofia inculturada": "aquela que levanta a pretensão de se articular no nível conceitual a partir do nível simbólico da sabedoria popular dos povos latino-americanos" (OLIVEIRA, 1997, p. 389); "uma tradução na esfera do especulativo da racionalidade sapiencial da sabedoria popular" (OLIVEIRA, 1997, p. 402).

f) Além dessas referências explícitas que indicam uma interlocução mais ou menos direta e consequente dessas teologias com determinados filósofos e/ou filosofias, seria possível identificar em diferentes autores/as e/ou textos teológicos latino-americanos referências filosóficas indiretas que, em geral, vão numa dupla e tensa direção: filosofias da práxis e filosofias hermenêuticas. Mas aqui não é possível sequer indicar esses autores e textos. Em todo caso, é importante chamar atenção para esse fato porque em geral as teologias da libertação se compreendem como teologias da práxis e/ou como hermenêuticas teológicas. Falam constantemente de práxis e de hermenêutica ou lugar hermenêutico, mesmo

\footnotetext{
${ }^{2}$ Essa linha aberta por Ellacuria em diálogo com Zubiri foi desenvolvida posteriormente de modo muito fecundo e original por Antonio González (GONZÁLEZ, 1993, p. 145-160; 1997; 1999; 2013).
} 
quando não explicitam com maior rigor sua compreensão de práxis, da relação teoria-práxis e de hermenêutica ou lugar hermenêutico, nem muito menos dialogam explicitamente com algum filósofo.

g) Uma questão específica que não podemos abordar aqui, pois exige um tratamento especial que extrapola os limites deste trabalho, diz respeito à chamada filosofia da libertação e, sobretudo, sua relação real e efetiva com as teologias da libertação. Em todo caso, convém chamar atenção para sua complexidade e pluralidade (ELLACURIA - SCANNONE，1992; SCANNONE，1992，p. 49-58; PRIMER ENCUENTRO MESOAMERICANO DE FILOSOFÍA, 1985; RAMAGLIA, 2011, p. 377-398; ORTIZ - ZÚNGA - GALINDO - MELCHOR, 2011, p. 399-417), tanto no que diz respeito às perspectivas filosóficas, quanto no que diz respeito à relação com o fazer teológico. Embora a expressão filosofia da libertação apareça sempre associada ao nome de Enrique Dussel (DUSSEL, 1980; 1985; R. ZIMMERNANN, 1987; LAMPE, 1995), essa é apenas uma de suas correntes. Há várias outras, dentre elas as que foram desenvolvidas por Ignacio Ellacuria e Juan Carlos Scannone. Para não falar de outras perspectivas filosóficas desenvolvidas no continente em profunda sintonia com os movimentos e as teologias da libertação como, por exemplo, a filosofia de Manfredo Oliveira (OLIVEIRA, 1993; 1995a; 1995b; 1997; 2000; 2001; 2010; 2013). Além do mais, haveria que analisar até que ponto a filosofia da libertação de Enrique Dussel repercutiu efetivamente nas teologias da libertação. Mas isso extrapola os limites deste trabalho. Em todo caso, não se pode deixar de destacar sua importância na interlocução mais ou menos direta e explícita de muitos teólogos da libertação com a filosofia de Emmanuel Levinas, particularmente com a categoria de "alteridade" (SUSIN, L. C. 1984; 1987; 2000; 2001). 


\section{B. Perspectivas e/ou orientações fundamentais}

No item anterior identificamos em diferentes escritos e/ou correntes de teologia da libertação um conjunto de referências filosóficas diretas ou indiretas. Elas parecem indicar, ainda que de modo um tanto genérico e indeterminado, a predominância de uma dupla e tensa perspectiva ou orientação filosófica fundamental entre as teologias da libertação que convém indicar, embora não tenhamos condição de desenvolver aqui adequadamente essa questão: práxis e/ou hermenêutica.

Talvez devamos situar essas perspectivas ou orientações filosóficas fundamentais e, sobretudo, sua assunção direta ou indireta pelas teologias da libertação no contexto amplo e complexo da nova atitude filosófica desencadeada pelo lema da filosofia de Husserl: “às coisas mesmas" (zu den Sachen selbst!). Não vamos entrar aqui na discussão sobre o modo como Husserl desenvolveu esse seu projeto filosófico (redução das coisas a correlato objetivo e ideal da consciência) nem na discussão sobre o estatuto teórico da fenomenologia e de suas várias correntes ou perspectivas. Importa simplesmente chamar atenção para o fato de que a fenomenologia provocou (abriu, forçou) uma volta filosófica às coisas mesmas (outra questão é a compreensão das coisas e do caminho para as coisas de cada fenomenólogo/a...). E isso parece sintonizar bastante com teologias que querem, a partir e na perspectiva da fé cristã, compreender e transformar a realidade como são as teologias da libertação. Talvez isso explique a tendência difusa à ruptura com a filosofia clássica (filosofia "perene") e a simpatia ou sintonia com essas filosofias ou intuições filosóficas (filosofias fenomenológicohermenêutico-práxicas).

Conforme indicamos, essa volta "fenomenológica" às coisas parece ter se dado na América Latina predominantemente numa dupla e tensa direção: práxica e/ou hermenêutica. Já chamamos atenção para o fato de que em geral as teologias 
da libertação se entendem como teologias da práxis e/ou como teologias hermenêuticas e que, por isso mesmo, fala-se tanto nessas teologias de práxis, de relação teoria-práxis, de hermenêutica, de lugar hermenêutico. Outra questão é a compreensão e o nível de elaboração que elas têm de práxis, da relação teoriapráxis, de hermenêutica, de lugar hermenêutico e, inclusive, da relação práxishermenêutica.

No que diz respeito à "relação" entre essas duas perspectivas filosóficas fundamentais há uma tensão raramente explicitada e nunca desenvolvida nas teologias da libertação. Em geral, admite-se que a hermenêutica tem implicações práticas e que a práxis possibilita novas interpretações. Portanto, não são questões opostas nem incompatíveis, como bem reconhece e indica Claude Geffré (GEFFRÉ, 1989, p. 28s, 59ss, 273ss; 2004, p. 54ss). Mas isso é suficiente? Tanto faz (do ponto de vista epistemológico e do ponto de vista práxico) falar da teologia como hermenêutica ou como momento teórico da práxis? Pode-se identificar sem mais teoria/teologia com hermenêutica, mesmo que da práxis? Não seria a hermenêutica um momento da teoria (teológica) que, por sua vez, é um momento da práxis (teologal)? Não é preciso avançar na determinação do estatuto teórico da "relação" hermenêutica-práxis? Isso não implica em última instância numa nova teoria da realidade e numa nova teoria da inteligência que se implicam e se condicionam mutuamente? São questões que "dão de pensar" e mostram a importância e necessidade do desenvolvimento da relação filosofia-teologia ou da mediação filosófica da teologia.

Convém, por fim, chamar atenção para o fato de que essas intuições e indicações filosóficas de orientação predominantemente fenomenológicohermenêutico-práxica se encontram, sobretudo, em teólogos/as e teologias de origem hispânica. No caso do Brasil, em geral, a ausência (!?) de uma mediação filosófica nas teologias da libertação é ainda maior e mais grave (ADÃO, 2015, p. 262). 


\section{Consequências positivas e negativas}

Vamos concluir essa primeira parte de nosso estudo chamando atenção para algumas consequências positivas e negativas da não tematização ou do pouco desenvolvimento da mediação filosófica nas teologias da libertação. Como nos itens anteriores, trata-se, aqui, também, apenas de um esboço da problemática sem maiores desenvolvimentos. Em todo caso, julgamos importante esse esboço, pois ele nos permite ponderar os ganhos e as perdas do caminho seguido, mostra a necessidade e urgência do desenvolvimento da mediação filosófica e oferece, inclusive, algumas pistas para um desenvolvimento adequado dessa mediação.

Antes de tudo, é preciso reconhecer que a ausência ou o pouco desenvolvimento da mediação filosófica nas teologias da libertação trouxe alguns benefícios para essas teologias (e mesmo para o conjunto das teologias na Igreja), não obstante suas ambiguidades e suas consequências negativas. Abriu espaço para um diálogo fecundo e criativo com as ciências humanas e com a sabedoria popular e, através delas, ofereceu um acesso privilegiado à realidade, tal como ela se apresenta, é experimentada e está configurada. Isso aproximou as teologias da libertação da vida concreta das pessoas e comunidades, recuperou/revigorou o caráter espiritual/eclesial do fazer teológico e tornou a teologia algo relevante e eficaz na vida da Igreja e na sociedade. Além do mais, e do ponto de vista estritamente epistemológico, o desenvolvimento dessas outras formas de saber e conhecimento no fazer teológico, ajuda a compreender que o processo de intelecção (também teológica!) é muito mais complexo do que parece à primeira vista e que não pode ser identificado e/ou reduzido a uma de suas formas como é a filosofia, tal como foi exercitada e desenvolvida tradição ocidental. E por mais importante e necessário que seja essa forma do saber.

Mas é preciso reconhecer também que a ausência ou o pouco desenvolvimento da mediação filosófica nas teologias da libertação trouxe consequências negativas para essas teologias, comprometendo, inclusive, aspectos 
positivos e fecundos de sua interlocução com as ciências humanas e com a sabedoria popular.

Em primeiro lugar, o fato de um teólogo não tematizar nem desenvolver a mediação filosófica de sua teologia não significa sem mais ausência de mediação filosófica em seu fazer e em seu produto teológicos. O que acontece, normalmente, na maioria dos casos, é um uso não refletido nem tematizado de conceitos e pressupostos filosóficos que condicionam o fazer e produto teológicos.

Em segundo lugar, esse uso não refletido nem tematizado de conceitos e pressupostos filosóficos acaba tornando a teologia escrava desses conceitos e pressupostos e incapaz de superar as ambiguidades desses mesmos conceitos e pressupostos. Noutras palavras, o uso não controlado da mediação filosófica leva consigo as ambiguidades dessa mediação para o fazer teológico e torna a teologia incapaz de controlar seu próprio discurso e superar suas próprias ambiguidades.

Em terceiro lugar, mesmo no caso das teologias indígena, negra e popular que se desenvolvem segundo uma lógica simbólico-sapiencial e não segundo uma lógica teórico-conceitual, a problemática da mediação filosófica não é completamente irrelevante nem deslocada: seja porque boa parte de seus autores são formados na cultura ocidental e não deixam de utilizar conceitos e pressupostos teórico-filosóficos; seja porque a mera indicação de lógicas diferentes de saber levanta problemas filosóficos acerca do saber em geral e do saber teológico em particular.

Em quarto lugar, convém recordar que parte das críticas feitas a essas teologias está ligada a conceitos e pressupostos teóricos (também filosóficos!) ambíguos e/ou não suficientemente elaborados e desenvolvidos e que dizem respeito, inclusive, ao assunto da teologia (historicidade da salvação) e seu estatuto teórico (teologia X ciências humanas). A não tematização e o não desenvolvimento da mediação filosófica acabam contribuindo para essas ambiguidades e 
dificultando um diálogo crítico e fecundo com as críticas que lhes são dirigidas e com os pressupostos filosóficos dessas críticas.

Em quinto lugar, a não tematização da mediação filosófica acaba comprometendo até mesmo aspectos positivos e fecundos da interlocução dessas teologias com as ciências humanas e com a sabedoria popular, bem como sua potencialização teórico-teológica: seja na medida em que leva ou pode levar a um novo reducionismo do saber (agora científico e/ou sapiencial), seja na medida em que não possibilita ou dificulta uma elaboração mais rica e complexa do saber em suas várias formas (sapiencial, científica, filosófica etc.).

Tudo isso aponta para a necessidade e urgência de tematização e desenvolvimento da mediação filosófica das teologias da libertação: uma mediação entre muitas outras, mas uma mediação importante e necessária. É o que faremos na segunda parte desse nosso estudo através de uma aproximação sistemática da problemática filosofia-teologia nas teologias da libertação.

\section{II - APROXIMAÇÃO SISTEMÁTICA}

Tendo apresentado um panorama histórico e feito um balanço crítico da problemática filosofia-teologia nas teologias da libertação, faremos, agora, uma abordagem mais sistemática dessa problemática, indicando sua importância, seu lugar e algumas de suas contribuições para o fazer e para o produto dessas teologias.

\section{Importância e lugar da mediação filosófica}

Convém começar essa abordagem sistemática do tema explicitando a importância e o lugar da mediação filosófica na teologia. O simples fato de a filosofia ter constituído uma mediação importante ou mesmo a mais importante do fazer teológico ocidental (NÉDONCELLE, 1965, p. 69-77; PANNENBERG, 2008; 
LIMA VAZ, 1986; JOÃO PAULO II, 1998; OLIVEIRA, 2000), não obstante os reducionismos e as consequências negativas desse fato, já é um indicativo de sua importância para a teologia e um indicativo que não deve ser banalizado nem minimizado. E o balanço crítico que esboçamos no final do item anterior acerca da não tematização ou do pouco desenvolvimento da mediação filosófica nas teologias da libertação aponta também para a importância e necessidade de se avançar nessa direção.

Falamos em avançar, pois não se trata simplesmente de uma volta ao passado (filosofia clássico-escolástica); uma volta que prescinda e menos ainda que negue sem mais as novas perspectivas filosóficas (filosofias modernas e contemporâneas) e as novas formas de saber (ciências em geral, sabedoria popular etc.). Trata-se, antes, da necessidade de uma concepção mais ampla e complexa do fazer teológico que reconheça e potencialize diferentes formas de fazer teologia e diferentes mediações do fazer teológico. Formas e mediações que não se contrapõem necessariamente, mas se complementam e se enriquecem mutuamente. E, aqui, a teologia ocidental e a mediação filosófica encontram um lugar e adquirem importância no conjunto do fazer teológico.

A própria expressão teologia é usada comumente num duplo sentido que convém explicitar: um sentido amplo (inteligência da fé) e um sentido estrito (inteligência racional da fé). A inteligência da fé é algo bem mais amplo e complexo que a inteligência racional da fé. Razão é um modo de inteligência. Quando falamos de inteligência racional da fé, falamos, aqui, concretamente, dessa forma específica de inteligência da fé que se deu mediante o encontro e a interação com a filosofia grega e que se convencionou chamar teo-logia: um discurso sobre Deus ou mais precisamente sobre a experiência de Deus mediado e regulado pelo logos.

Embora tenha sido tomada como sinônimo e, assim, identificada sem mais com a inteligência da fé, a teo-logia como discurso racional da fé nunca foi a única nem a forma predominante de inteligência da fé. Na verdade, a inteligência da fé se 
desenvolveu e se desenvolve muito mais de modo narrativo, simbólico, litúrgico, experiencial etc. que de modo teórico-conceitual.

Stephen Bevans, tratando da contextualidade da teologia, mais precisamente das formas que a teologia pode adquirir, reconhece que, desde a Idade Média e o início da escolástica, a teologia se constituiu como "disciplina acadêmica, científica" e assumiu a forma de "discurso" ou de exposição discursiva. Mas insiste que "a teologia nem sempre pode ser feita de maneira discursiva nem hoje deve ser feita necessariamente nessa linha" que é "tipicamente ocidental e fruto natural da cultura literária visual”.

Nem sequer no Ocidente a teologia foi feita sempre de forma discursiva: “Grandes aportes teológicos foram escritos em forma de hinos ou poemas (testemunho disso são os hinos de Efrém ou a surpreendente poesia de Tomás de Aquino)"; não se pode esquecer que a teologia também foi sendo feita "em forma de sermões ou homilias (por exemplo, os sermões de santo Agostinho sobre São João ou os sermões universitários de Newman)"; sem falar que "a teologia não tem sequer que ser verbal, pois sempre esteve encarnada em rituais”, como se pode comprovar pela "regra lex orandi, lex credendi" e pelo fato de "algumas das buscas de compreensão da fé mais eloquentes” estejam "plasmadas em obras de arte" (pintura, escultura etc.).

A “forma" que a teologia adquire está muito ligada ao "lugar" em que a teologia é feita (onde) ou para o qual ela é feita (para onde/quem). Vejamos alguns exemplos: "Na cultura africana a melhor forma de teologizar pode ser através de compilação, criação ou reflexão dos provérbios. Na cultura afro-americana, o sermão ou a homilia pode ser o melhor veículo para a teologização. Na Índia, a melhor maneira de expressar a fé pode ser através da dança. Em todo caso, o ponto que queremos destacar é que a teologia é uma atividade muito mais ampla que a simples erudição e que outras culturas têm formas diversas de articular a fé que são preferíveis [à forma ocidental]. Obras de arte, hinos, histórias, dramas, livros de 
caricaturas, cinema, todas são formas válidas para fazer teologia em culturas particulares" (BEVANS, 2004, p. 44s).

Não se trata, aqui, de formas opostas que se excluem mutuamente, mas de formas diversas de inteligência da fé que podem se enriquecer mutuamente, desempenhando, inclusive, função crítica uma em relação à outra.

A forma simbólico-sapiencial de fazer teologia pode desempenhar uma função crítica em relação à forma teórico-conceitual de fazer teologia: seja na medida em que revela que esta é apenas uma forma de saber e que há outras formas de saber; seja na medida em que se mostra mais adequada e capacitada para apreender e expressar a historicidade da salvação e sua parcialidade pelos pobres, tal como se deram na história de Israel e na práxis de Jesus de Nazaré - um limite do modo grego de pensar, para o qual vários teólogos têm chamado atenção (ELLACURÍA, 200oc, p. 519-533; 2000d, p. 597-628; MÜLLER, 2015，p. 34; KASPER, 2015, p. 24ss; MOLTMANN, 2013, p. 93).

Mas também a forma teórico-conceitual de fazer teologia pode desempenhar uma função crítica em relação à forma simbólico-sapiencial de fazer teologia: seja indicando ambiguidades e contradições em formas simbólico-sapienciais de apreensão e expressão da experiência cristã de Deus; seja buscando apreender e expressar (nos limites de suas possibilidades teórico-conceituais!?) de forma menos ambígua e mais adequada essa mesma experiência cristã de Deus.

E essa forma teórico-conceitual de fazer teologia tem um momento filosófico fundamental. Segundo Antonio González, a filo-sofia é uma forma de saber que tem uma tríplice característica: ultimidade (problematização do sentido comum, radicalização, busca da raiz ou do fundamento)33, criticidade (distância, dúvida,

\footnotetext{
3 “A filosofia é sempre problematizadora do que o 'sentido comum' considera como evidente [...] o próprio da filosofia é ir além das explicações do sentido comum [...]. A filosofia é radicalização; é um saber radical porque pretende chegar ao fundamento, à raiz última das afirmações que nós encontramos na sabedoria popular e no sentido comum" (GONZÁLEZ, 2005, p. 30).
} 
suspeita)4, praticidade (interesse, emancipação)5. Características que, mais cedo ou mais tarde, de uma forma ou de outra, emergem e se impõem no processo de inteligência de qualquer experiência religiosa (GONZÁLEZ, 2005, p. 353s) e, concretamente, da fé cristã.

Aliás, já em Platão, a expressão teologia indica um discurso crítico-racional sobre os deuses; uma espécie de mito-logia, isto é, um discurso sobre os deuses mediado/regulado pelo logos (PLATÃO, 2000, I, 379a-383c). Trata-se de uma forma de inteligência (logos) que nasce da suspeita/crise de formas habituais de compreensão e discurso sobre os deuses (mitos) e como busca de seu saber/conhecimento último (filo-sofia). E é nesse sentido preciso de discurso racional que essa expressão foi, não sem tensão, sendo assumida pela Igreja e acabou se tornando sinônimo de inteligência da fé (BOFF, 1998, p. 548-560).

Certamente, como temos indicado, essa não é a única forma nem a primeira forma nem sequer a forma mais habitual de inteligência da fé. Pelo contrário. Surge normalmente em meio a tensões e/ou em contextos de crise de formas habituais de inteligência da fé. E surge como radicalização dessas tensões ou crises (momento crítico-destrutivo) em busca de apreensões e expressões menos ambíguas e mais adequadas da experiência cristã de Deus ou da fé cristã (momento crítico-criativo).

Neste sentido, podemos afirmar que o filosofar ou a mediação filosófica é um momento constitutivo e necessário do processo amplo e complexo de inteligência da fé. Falamos de filosofia, aqui, mais como atitude filosófica (busca da sabedoria) que como teoria filosófica concreta (posse de um saber). A inteligência da fé é algo complexo, dinâmico, processual, sempre aberto e algo que se dá de muitas formas e

\footnotetext{
4 "O filósofo é alguém que toma distância, que se afasta dos modos habituais de pensar para elaborar uma reflexão própria, um modo de ver as coisas distinto do que lhe proporcionou a sociedade na qual nasceu [...] Isso leva o filósofo a adotar uma atitude de dúvida. As coisas não são tão evidentes como parecem; é preciso duvidar; é preciso pôr em questão o que todos admitem [...]; além de duvidar, o filósofo é alguém que suspeita [...] e se pergunta para que serve esta ideia, para que serve um determinado pensamento ou crença que todos consideram acertado [...] A filosofia suspeita que as ideias podem servir para ocultar grandes verdades ou para manter os interesses dos poderosos" (GONZÁLEZ, 2005, p. 30s).

5 "Mas estas tarefas de radicalização e de desmascaramento a que nos referimos [...] não são realizadas por pura curiosidade ou por esporte. O filósofo [...] está movido por algo que está além do puro interesse científico: a filosofia atua em última instância por interesses emancipadores ou libertadores dos homens" (GONZÁLEZ, 2005, p. 31).
} 
adquire muitas expressões. E o momento filosófico da inteligência da fé tem a ver com a inquietação ou mais precisamente com a radicalização da inquietação que dinamiza o processo de inteligência da fé e com a busca de apreensão e expressão mais adequadas da fé. Daí porque, embora nem toda forma de inteligência da fé desenvolva ou precise desenvolver uma atitude filosófica, mais cedo ou mais tarde isso se torna inevitável e mesmo necessário. Tanto no que diz respeito a conteúdos teológicos concretos, quanto no que diz respeito ao processo de inteligência da fé enquanto tal. E, assim, o filosofar emerge como momento constitutivo e necessário do processo de inteligência da fé.

Foi uma das grandes teses e insistências de Rahner (RAHNER, 2007, p. 8493; 1989, p. 37-39; FRANÇA MIRANDA, 1975, p. 106-122; OLIVEIRA, 2004, p. 201-218), embora sua redução da expressão teologia ao sentido estrito de teologia racional seja discutível e sua formulação da relação filosofia e teologia em analogia com a problemática da relação "natureza e graça” mesmo que mediada pelo conceito "existencial sobrenatural" não deixe de ser uma formulação ambígua e problemática (GONZÁLEZ, 1989, p. 341-349; 1999, p. 32-42; AQUINO JÚNIOR, 2011, p. 90s). Em todo caso, insiste e mostra, a seu modo, que o filosofar não é algo estranho à teologia, mas um momento interno constitutivo e necessário do processo de inteligência da fé. Outra questão, que abordaremos mais adiante, tem a ver com a mediação ou (por que não?) com as mediações filosóficas concretas da teologia.

E, assim, podemos afirmar com Rahner e para além de Rahner que, embora não toda teologia concreta precise se desenvolver como teologia filosófica e consequentemente necessite desenvolver uma mediação filosófica, a teologia, em seu conjunto, tem em um momento filosófico constitutivo inevitável e necessário. O que nos leva a afirmar, de novo com Rahner e para além de Rahner, que, em algum momento e de algum modo, “é necessário filosofar na teologia” (OLIVEIRA, 2004, p. 201-218). 


\section{Contribuições da mediação filosófica}

Esse momento filosófico da teologia diz respeito tanto a conteúdos concretos abordados e/ou desenvolvidos (temas), quanto ao próprio fazer teológico enquanto tal em sua estrutura fundamental de "saber de algo" (conhecimento-realidade) dois aspectos distintos que se implicam mutuamente; afinal, só se faz teologia teologizando sobre algo e todo teologizar sobre algo é uma forma de saber. Mas diz respeito também à questão da mediação ou das mediações filosóficas a serem apropriadas e/ou desenvolvidas na teologia (que filosofia ou que filosofias?).

Não vamos desenvolver aqui nenhum desses três aspectos referentes à mediação filosófica da teologia: conteúdos teológicos, fazer teológico, mediação filosófica. Vamos simplesmente explicitá-los e, assim, mostrar sua importância e necessidade.

\section{A. Conteúdos concretos}

Comecemos por um ponto que pode ser reconhecido e admitido sem maiores dificuldades. A teologia trata de muitos temas: Deus, fé, pessoa/ser/animal humano, sociedade, história, mundo, mal, sacramento, salvação, moral etc. Trata tudo isto a partir de Deus ou mais concretamente da experiência de Deus. E o faz com linguagens as mais diversas: narrativas, imagens, ritos, símbolos, conceitos etc.

Todas essas linguagens expressam e medeiam certa compreensão das realidades abordadas (temas) e da perspectiva em que elas são abordadas (assunto ou ponto de vista). A questão reside em saber se essa compreensão e essa linguagem são as mais adequadas e se não são possíveis compreensões e linguagens mais adequadas. E, aqui, a filosofia tem um lugar e uma tarefa fundamentais. Antes de tudo, enquanto atitude de crítica e de busca radicais. Mas também, e mais do 
pode parecer e do que normalmente se reconhece, enquanto teoria concreta pressuposta - implícita ou explicitamente, consciente ou inconscientemente. Basta ver a quantidade de ideias e conceitos filosóficos presentes e/ou pressupostos nas mais diversas e distintas teologias.

Nesse sentido, é fundamental desenvolver o momento filosófico da teologia no tratamento de qualquer tema concreto e mesmo de seu assunto próprio e específico: seja problematizando as concepções expressas/mediadas na compreensão e na linguagem sobre os temas ou assunto abordados, bem como seus pressupostos e suas implicações prático-teóricos (momento crítico-destrutivo); seja buscando uma compreensão e uma linguagem menos ambíguas e mais adequadas do tema ou assunto em questão (momento crítico-criativo).

Isso vale, em primeiro lugar, para as teologias desenvolvidas na tradição ocidental, mesmo as que reagem explicitamente a essa forma de fazer teologia como, por exemplo, Tertuliano, Pedro Damião, Lutero, Barth e Jüngel. Elas são profundamente marcadas em suas compreensões e em seus conceitos pela reflexão e pelas teorias filosóficas desenvolvidas no Ocidente, embora nem sempre de modo explícito e consciente ${ }^{6}$. Mas vale também para teologias desenvolvidas em outras tradições, como, em parte, as teologias indígena, negra e popular. Além de serem, de alguma forma e em alguma medida, marcadas também pela tradição ocidental, suas compreensões e suas linguagens não estão imunes a ambiguidades e contradições. E, dados a abertura e o dinamismo que as constitui, podem ser alargadas e reelaboradas.

\footnotetext{
${ }^{6}$ Assim, "a teoria estoica do espírito e sua visão de corporeidade do espírito" permitiu a Tertuliano afirmar também "a corporeidade de Deus"; embora Pedro Damião rejeite a autonomia irrestrita da dialética frente à teologia, não rejeita "a dialética em si"; Lutero, além de ter professado em seu período inicial ser ockhamista, "chegou a defender a tese estoica de Lorenzo Valla e John Wiclif de que tudo acontece por necessidade, como descrição do agir onipotente de Deus e de sua providência" (PANNENBERG, 2008, p. 18-20); Karl Barth "concebe o Deus cristão utilizando a categoria filosófica de sujeito" e mesmo quando Jüngel "recorre à revelação cristã para eliminar aqueles conceitos metafísicos que resultam incompatíveis com as exigências conceituais dessa revelação", continua sendo condicionado por "certos pressupostos filosóficos" como, por exemplo, "a ideia do mal como negatividade" (GONZÁLEZ, 1999, p. 73s).
} 


\section{B. Fazer teológico}

A mediação filosófica da teologia se mostra particularmente importante e necessária quando se trata de refletir sobre o próprio fazer teológico enquanto tal, isto é, quando está em jogo a questão mesma do teologizar em sua dupla dimensão de saber (logos) sobre algo (Deus - experiência de Deus). É toda a problemática do método teológico,

entendido não no sentido do metódico, isto é, da análise das técnicas de investigação e de exposição, mas no sentido do metodo-lógico, isto é, da razão própria do inteiro proceder pelo qual transcorre a reflexão teológica como elemento essencial da práxis eclesial. (ELLACURÍA, 2000b, p. 220).

Está em jogo, aqui, não simplesmente a abordagem de um tema específico na teologia, mas a própria especificidade da abordagem teológica. E tanto no que diz respeito ao assunto da teologia (experiência de Deus), quanto no que diz respeito ao acesso intelectivo a esse assunto (saber/logos). Duas dimensões do mesmo problema; dimensões que se implicam e se condicionam mutuamente. Afinal, se, por um lado, só podemos falar de Deus a partir do acesso que temos a ele; por outro lado, nosso acesso a ele está possibilitado e condicionado por sua presença em nossa vida. Noutras palavras, se Deus não existisse nem se fizesse presente em nossa vida não teríamos acesso a ele nem poderíamos falar dele. Só podemos falar dele porque temos acesso a ele e nossa fala sobre ele está possibilitada e condicionada por esse acesso. Em linguagem teológica: o saber/conhecimento de Deus (teologia) é inseparável da experiência de Deus (revelação-fé) ou, para sermos mais precisos, a teologia (saber/conhecimento) é um momento da fé (experiência/práxis).

Tudo isso tem enormes implicações para a determinação do assunto da teologia e da própria intelecção teológica. E isso não se pode desenvolver nem muito menos levar a termo sem uma mediação filosófica mais ou menos adequada. Embora não possamos desenvolver neste trabalho nenhuma dessas questões, 
queremos ao menos problematiza-las e indicar um caminho para seu adequado desenvolvimento.

\section{a) Assunto da teologia}

Importa, aqui, simplesmente, chamar atenção para o fato de que a teologia cristã está possibilitada e condicionada pela experiência de Deus em Israel e, definitivamente, na vida de Jesus de Nazaré. Ela é a referência, a norma e o critério últimos e definitivos do que sabemos e do que podemos dizer sobre Deus. O discurso cristão sobre Deus é inseparável de sua presença/ação na história de Israel e na vida de Jesus de Nazaré. A tal ponto, que ele será nomeado não como Deus simplesmente, mas como Pai (de Jesus Cristo, antes de tudo e em sentido próprio!): “Creio em Deus Pai...”.

E, aí, Deus se mostra presente e atuante na história (por mais transcendente que seja: transcendente na história e não $d a$ história), partidário dos pobres e marginalizados: pobre, órfão, viúva, estrangeiro (por mais universal que seja em seu amor e em seu desígnio salvífico). De modo que nenhum discurso sobre Deus e sobre a experiência de Deus que prescinda e menos ainda que se contraponha à sua atuação histórica e parcial pelos pobres e marginalizados pode ser tido como cristão em sentido estrito. E nenhuma mediação filosófica que prescinda ou, pior ainda, que negue ou comprometa a historicidade e parcialidade da ação de Deus e da experiência de Deus é adequada ou pelo menos suficiente para fazer teologia cristã.

Com isso, tocamos num dos pontos críticos da mediação filosófica clássica utilizada pela teologia ocidental: sua dificuldade ou mesmo sua incapacidade teórico-conceitual de apreender e expressar adequadamente a historicidade e, sobretudo, a parcialidade da ação salvífica de Deus como algo que diz respeito à realidade mesma de Deus e não como algo secundário e/ou irrelevante (Afinal, só 
podemos falar de Deus a partir do acesso que temos a ele e seria contraditório pensar que Deus se revelasse/agisse em contradição com sua própria realidade: se ele age tomando partido pelos pobres e marginalizados é porque a parcialidade pelos pobres e marginalizados diz respeito à sua própria realidade - é em si mesmo um Deus parcial e por isso se revela/age tomando partido pelos pobres e marginalizados). É o que, em perspectivas, formas e intensidades diversas, tem indicado teólogos tão diferentes como Ignacio Ellacuria, Jürgen Moltmann, Gerhard Müller e Walter Kasper (ELLACURÍA, 20ooc, p. 519-533; 200od, p. 597628; MÜLLER, 2015, p. 34; KASPER, 2015, p. 24Ss; MOLTMANN, 2013, p. 93), entre outros.

Vejamos, a modo indicativo e provocativo, o que diz Kasper a propósito do "esquecimento" (!?) da misericórdia na teologia sistemática, particularmente na doutrina sobre Deus - inclusive na sua (KASPER, 2015, p. 22s, nota 36):

A razão desse tratamento negligente da misericórdia manifesta-se quando se observa que, nos manuais, são os atributos divinos que resultam da essência metafísica de Deus enquanto ser subsistente (ipsum esse subsistens) os que ocupam o primeiro plano: simplicidade, infinitude, eternidade, onipresença, onisciência, onipotência etc. A determinação metafísica da essência divina, que impregnou toda a tradição teológica desde os primeiros tempos da Igreja, não tem, de modo algum, de ser radicalmente questionada; no entanto, temos de nos ocupar de sua legitimidade e de seus limites. Trata-se aqui unicamente de mostrar que, no marco dos atributos metafísicos divinos, apenas existe lugar para a misericórdia, a qual não resulta da essência metafísica de Deus, mas sim de sua autorevelação histórica [...] Nestes termos, esquecer a misericórdia não é um problema marginal e secundário da doutrina de Deus; antes pelo contrário, isso confronta-nos com o problema fundamental da determinação da essência de Deus e dos atributos divinos em geral, e obriga-nos a reformular a doutrina de Deus (KASPER, 2015, p. 24).

$\mathrm{Na}$ raiz do problema indicado por Kasper está em jogo nada menos que "o ponto de partida metafísico tradicional da doutrina de Deus" (KASPER, 2015, p. 24). E, embora não haja aqui uma negação radical da mediação filosófica clássica, há, sem dúvida nenhuma, o reconhecimento de seus limites teórico-conceituais para apreender e expressar o Deus que se revela na história de Israel e, definitivamente, na história/práxis de Jesus de Nazaré. O que implica na 
necessidade de buscar uma mediação filosófica mais adequada para o discurso cristão sobre Deus.

\section{b) Intelecção teológica}

Nunca é demais insistir no fato de que teologia é sempre inteligência da fé, seja entendida num sentido amplo (diferentes formas de saber), seja entendida num sentido estrito (saber racional). Mas a discussão acerca do processo humano de intelecção (também da fé!) é algo extremamente complexo que não podemos sequer esboçar. Em todo caso, é possível reconhecer e/ou identificar no debate acerca da intelecção humana no Ocidente (GONZÁLEZ, 2005, p. 45-105) duas grandes tendências, não obstante a variedade enorme de suas compreensões e formulações antigas ou recentes. Essas tendências podem ser nomeadas, ainda que de modo ambíguo e um tanto caricaturesco, em termos de idealismo e realismo, entendendo por esses termos simplesmente uma concepção do processo de intelecção mais ou menos como algo absoluto ou substantivo (Inteligência) ou como momento ou nota da vida humana (momento inteligente). E qualquer dessas tendências tem enormes consequências para o fazer e para o produto teológicos, determinando em última instância sua orientação ou direção fundamental.

No caso concreto das teologias da libertação, elas sempre foram compreendidas em referência essencial e constitutiva à práxis de libertação. Embora com concepções distintas da práxis e de seu vínculo com a teoria, as primeiras gerações de teólogos da libertação sempre entenderam a TdL como uma teologia da práxis: "um momento do processo por meio do qual o mundo é transformado" (GUTIÉRREZ, 2000, p. 74); uma espécie de praxeologia da libertação (ASSMANN, 1973, p. 62-65); “momento consciente e reflexo da práxis eclesial” (ELLACURÍA, 200og, p. 163-185); “teologia do político e suas mediações” (BOFF, 1983); "intelectus amoris" (SOBRINO, 1992, p. 47-80), entre outros. E todas as teologias da libertação (feminista, negra, indígena, ecológica, religiosa e inter-religiosa, gay etc.) estão vinculadas a processos históricos de libertação. 
Essa referência fundamental à práxis diz respeito antes de tudo à ação pastoral-evangelizadora da Igreja, particularmente em sua dimensão sociolibertadora ligada às lutas e aos movimentos populares (GUTIÉRREZ, 20ob, p. 27-32; 2008, p. 29-40). Mas ela tem também muitas implicações e consequências epistemológicas que não são fáceis de captar e que entram em conflito com a concepção hegemônica de saber desenvolvida ao longo da tradição ocidental, marcada por um dualismo mais ou menos radical e maniqueísta entre "sentir" e "inteligir" e por uma concepção idealista do saber. Concepção, aliás, bastante presente nas teologias da libertação.

Gustavo Gutiérrez intuiu e até esboçou essa problemática epistemológica da teologia em sua respectividade com a práxis (GUTIÉRREZ, 2000, p. 57-74; 200ob, p. 107-128). Mas Ignacio Ellacuría foi o teólogo que desenvolveu e formulou essa problemática do modo mais amplo e consequente entre os teólogos da libertação (ELLACURÍA, 2000g, p. 163-185; 2000a, p. 187-218; 2000e, p. 235-245; AQUINO JÚNIOR, 2010, p. 213-264; 2011, p. 83-102). E o fez tomando como referencial teórico a teoria da inteligência de Xavier Zubiri: Inteligência sentiente (ZUBIRI, 2011abc).

Diferentemente de outros modos de fazer teologia, cuja preocupação e orientação fundamentais residem na busca e "compreensão do sentido" das afirmações dogmáticas ou da positividade da fé (interpretação), a preocupação e orientação fundamentais da TdL residem na realização histórica da salvação, isto é, na "transformação da realidade e, nela, a transformação da pessoa" (práxis). Frente a teologias predominantemente "intelectualistas", centradas nas ideias, no diálogo cultural, na lógica discursiva etc, a TdL é uma teologia predominantemente "realista" e práxica, centrada na realidade que procura inteligir (e não na ideia ou conceito dessa realidade) e em sua realização histórica, isto é, na busca de mediações concretas de sua efetivação (e não apenas na busca de seu sentido) (ELLACURÍA, 2000a, p. 200). Certamente, interessa à TdL o sentido das afirmações teológicas, mas em função de sua realização histórica, como um 
momento do processo de realização da salvação.

Essa afirmação do primado da práxis sobre o sentido não é uma afirmação gratuita feita em função de algum ativismo pastoral ou político e em prejuízo da atividade estritamente teórica. Ela está fundamentada na análise da própria intelecção humana. Ao contrário do que se costuma pensar, a intelecção não é primariamente especulação (teórica), mas um modo de enfrentamento (práxico) e não consiste formalmente em “compreensão de sentido”, mas em "apreensão de realidade" (ELLACURÍA, 2000a, p. 202-211). É claro que todas as coisas, enquanto apreendidas intelectivamente, adquirem algum sentido na vida humana que é preciso explicitar. Mas o sentido, enquanto sentido da coisa apreendida, está fundado na coisa mesma e sua interpretação pressupõe sua apreensão. De modo que, primária e formalmente, a intelecção consiste em "apreender a realidade" e em “enfrentar-se com ela” como "realidade” (ELLACURÍA, 2000a, p. 207s).

Levar a sério esse caráter fundamentalmente práxico da teologia tem enormes consequências para o fazer teológico, para o produto teológico e para a fecundidade e eficácia pastorais da teologia. É que o interesse e a orientação fundamentais de uma teologia qualquer determina decisivamente seu processo, seu resultado e sua utilidade. "Se a teologia partisse, por exemplo, da pergunta pelo sentido da vida, o diálogo cultural entre as distintas cosmovisões se situaria no primeiro plano de interesse, enquanto se relegariam outros problemas humanos a um segundo plano ou se excluiria do plano da teologia”. Se, ao invés, ela parte de um interesse e de uma orientação práxicos, o acento cai na problemática das possibilidades ou das mediações de sua realização histórica. "A eleição adequada do ponto de partida [entendido como interesse ou orientação fundamentais] da teologia pode determinar decisivamente a formulação da mensagem que o cristianismo quer transmitir a uma humanidade atravessada por enormes conflitos" (GONZÁLEZ, 1995, p. 669). 


\section{Mediação filosófica}

Por fim, é importante tocar também na problemática da mediação filosófica da teologia. Problemática que diz respeito tanto à questão da mediação ou das mediações filosóficas concretas a serem assumidas e/ou desenvolvidas na teologia, quanto à questão de seu desenvolvimento na teologia.

\section{a) Mediações filosóficas concretas}

A explicitação da importância e do lugar da filosofia na teologia deixou em aberto a questão da mediação ou (por que não!?) das mediações filosóficas concretas da teologia. O desenvolvimento dessa questão passa pela consideração da prioridade do filosofar sobre as teorias filosóficas concretas e pelo discernimento da teoria ou das teorias filosóficas mais adequadas para a teologia.

Por um lado, é preciso considerar que a mediação filosófica da teologia diz respeito antes de tudo e acima de tudo ao filosofar ou a atitude filosófica e não a uma teoria filosófica específica. O momento filosófico da teologia, conforme explicitamos acima, tem a ver com a problematização radical de compreensões e linguagens teológicas habituais ou hegemônicas e com a busca de compreensão e linguagem teológicas mais radicais e adequadas. Ele é exercitado e desenvolvido normalmente em relação a teologias concretas - simbólico-sapienciais ou teóricoconceituais. E, embora recorrendo a teorias filosóficas concretas em seu desenvolvimento, deve ter sempre prioridade sobre elas, uma vez que essas mesmas teorias mais cedo ou mais tarde serão abordadas filosoficamente. Daí que a insistência na mediação filosófica da teologia tenha a ver, em primeiro lugar, com o filosofar ou com a atitude filosófica e não com uma teoria filosófica específica. Mesmo que não se possa separar radicalmente o filosofar da teoria filosófica, na medida em que todo filosofar pressupõe e/ou implica uma teoria filosófica, é necessário distingui-los e conceder prioridade ao filosofar. Do contrário, terminar- 
se-á comprometendo o caráter de ultimidade, radicalidade e praticidade que caracteriza a filosofia ou mesmo transformando-a em ideologia.

Por outro lado, é preciso discernir que teoria ou que teorias filosóficas são mais adequadas tanto para o desenvolvimento de determinados temas teológicos quanto para a reflexão e explicitação do próprio fazer teológico. E, aqui, a teologia, hoje mais que nunca, tem que dialogar com teorias filosóficas diversas e até (ao menos aparentemente) contraditórias, na medida em que possam ajudar a apreender e expressar aspectos da realidade teologal e do próprio teologizar. O fato de uma teoria filosófica determinada não ser suficiente como mediação filosófica da teologia (se é que alguma teoria filosófica é suficiente e absolutamente adequada para a teologia), não significa que não possa ser assumida parcialmente por ela. Com isto, não estamos afirmando que todas as teorias filosóficas são igualmente adequadas. Há teorias muito mais abrangentes e adequadas que outras, capazes, inclusive, de assumir outras teorias ou aspectos dessas teorias como momento interno de uma compreensão e formulação mais abrangente e adequada. Importa, em todo caso, saber que, enquanto momento do teologizar, a mediação ou as mediações filosóficas estão a serviço da apreensão e expressão da realidade teologal e são mais ou menos legitimas e adequadas na medida em que são capazes de apreender e expressar mais ou menos adequadamente essa realidade.

\section{b) Desenvolvimento da mediação filosófica}

Uma última questão acerca da mediação filosófica da teologia tem a ver com a problemática do desenvolvimento dessa mediação na teologia.

Antes de tudo, devemos nos perguntar se o desenvolvimento da mediação filosófica da teologia é tarefa do teólogo ou mesmo se o teólogo tem competência para isso. É verdade que, na medida em que é o teólogo quem faz teologia, é ele quem tem que desenvolver esse momento racional ou filosófico da teologia. Mas 
não é sua tarefa nem sua competência analisar exaustivamente as teorias e os conceitos filosóficos utilizados e/ou pressupostos no discurso teológico nem desenvolver exaustivamente uma teoria filosófica como mediação filosófica adequada da teologia: seja porque isso não é propriamente tarefa da teologia (GONZÁLEZ, 1999, p. 75), seja porque o teólogo como tal não tem competência para isso. O próprio Rahner que tanto valorizou e desenvolveu a mediação filosófica de sua teologia reconhece e adverte que "uma pretensão como essa seria excessiva para o teólogo, que pode ser filósofo só de uma maneira muito limitada” (RAHNER, 2004, p. 88s).

Além do mais, é preciso saber se é mesmo necessário um desenvolvimento exaustivo da mediação filosófica na teologia ou, de novo com Rahner, a propósito do conceito de filosofia transcendental em sua teologia, se isso não seria de "utilidade duvidosa, justamente por ser discutível para os objetivos da compreensão e do trabalho prático da teologia transcendental”. Neste contexto, afirma:

Temos, portanto, o direito de partir de um conceito de filosofia transcendental em parte impreciso, quase vulgar, mas justamente por isso capaz de compreender até fenômenos heterogêneos da moderna história da filosofia. Mesmo porque [...] tal conceito de filosofia transcendental pode ser aplicado também a questões imanentes à teologia considerada em si mesma, ou seja, não depende essencialmente de um consenso universal dos filósofos (RAHNER, 2004, p. 89).

De modo que, se o teólogo não pode se eximir do filosofar em seu trabalho teológico, já que o filosofar é um momento interno constitutivo do teologizar, e, assim, em alguma medida e de alguma maneira deve ser também filósofo, tampouco pode assumir para si a tarefa de desenvolver exaustivamente uma teoria filosófica. Além de não ser sua tarefa própria como teólogo, podendo, inclusive, desviá-lo de sua tarefa propriamente teológica; enquanto teólogo, não tem competência para isto. Em todo caso, deve filosofar em seu trabalho teológico e deve enfrentar-se crítica e criativamente com teorias filosóficas concretas, 
assumindo as teorias ou aspectos das teorias que se mostram mais adequadas e fecundas em seu trabalho teológico.

\section{A modo de conclusão}

Convém concluir esse estudo sobre a relação filosofia e teologia na América Latina insistindo no fato de que sua pretensão não era propor uma mediação filosófica específica para as teologias da libertação, mas simplesmente problematizar essa relação: Seja no que diz respeito à sua efetivação histórica (aproximação historiográfica); seja no que diz respeito à sua importância e necessidade (aproximação sistemática).

É verdade que o desenvolvimento dessa problemática não se dá sem uma mediação filosófica mais ou menos explícita e ou desenvolvida, como se pode verificar nas referências filosóficas fundamentais presentes, sobretudo, na segunda parte do trabalho e melhor desenvolvidas em outros estudos do autor, particularmente sua tese doutoral e um conjunto de artigos que tratam de questões epistemológicas das teologias da libertação (AQUINO JÚNIOR, 2010; 2012; 2017).

Em todo caso, nossa pretensão nesse trabalho é mais modesta e mais fundamental. Mais modesta por não pretender desenvolver nem sequer esboçar de modo abrangente uma mediação filosófica concreta para as teologias da libertação. Mais fundamental porque problematiza a questão tanto em seu desenvolvimento histórico quanto em sua estrutura teórica fundamental.

E, assim, põe-nos diante do desafio e da tarefa de desenvolver a mediação filosófica das teologias da libertação. Não como a única, nem como a primeira, nem como mais importante, nem como a mais urgente mediação da teologia. Mas, em todo caso, como uma mediação entre outras; como uma mediação importante $e$ necessária no processo global de inteligência da fé; e como uma mediação plural e complexa, desenvolvida em diálogo crítico-criativo com diferentes filosofias. 


\section{REFERÊNCIAS}

ADÃO, Francys Silvestrini. A carne se fazendo verbo: uma contribuição ao debate teológico no Brasil. Perspectiva Teológica, Belo Horizonte, v. 47, n. 132, p. 243$268,2015$.

ANDRADE, Paulo Fernando Carneiro. Fé e eficácia. O uso da sociologia na teologia da libertação. São Paulo: Loyola, 1991.

AQUINO JÚNIOR, Francisco de. A teologia como intelecção do reinado de Deus: O método da teologia da libertação segundo Ignacio Ellacuría. São Paulo: Loyola, 2010.

AQUINO JÚNIOR, Francisco de. O caráter práxico da teologia: abordagem epistemológica. Perspectiva Teológica, Belo Horizonte, v. 43, n. 119, p. 83-102, 2011.

AQUINO JÚNIOR, Francisco de. O caráter práxico-social da teologia: Tópicos fundamentais de epistemologia teológica. São Paulo: Loyola, 2017.

AQUINO JÚNIOR, Francisco de. Teologia e ciências sociais. Horizonte, Belo Horizonte, v. 10, n. 28, p. 1337-1367, out./dez. 2012. Disponível em: <http://periodicos.pucminas.br/index.php/horizonte/article/view/P.21755841.2012v10n28p1337/4725>. Acesso em: 12 jun. 2016.

AQUINO JÚNIOR, Francisco de. Teoria teológica - práxis teologal: Sobre o método da teologia da libertação. São Paulo: Paulinas, 2012.

ASSMANN, Hugo. Teología desde la praxis de la liberación. Ensayo teológico desde la América dependiente. Salamanca: Sígueme, 1973.

BEVANS, Stephen. Modelos de Teología Contextual. Edición revisada y aumentada. Quito: Verbo Divino; Spiritus, 2004.

BOFF, Clodovis. O rigor científico: princípios elementares extraídos de Aristóteles no interesse da teologia. Horizonte, Belo Horizonte, v. 13, n. 39, p. 1559-1579, jul./set. 2015, Disponível em:

<http://periodicos.pucminas.br/index.php/horizonte/article/view/P.2175-

5841.2015v13n39p1559/8641>. Acesso em: 29 maio 2016.

BOFF, Clodovis. Teoria e Prática. Teologia do político e suas mediações. Petrópolis: Vozes, 1983.

BOFF, Clodovis. Teoria do Método Teológico. Petrópolis: Vozes, 1998. 
BOFF, Clodovis. Volta ao Fundamento: Réplica. REB, Petrópolis, n. 272, p. 892927, 2008.

CORBAN, Jean - VANHOYE, Albert. Conhecer. In: LEÓN-DUFOUR, Xavier. Vocabulário de teologia bíblica. Petrópolis: Vozes, 1972, p. 165-169.

CORONADO, Jesús Castillo (org. e entrevistador). Livres e responsáveis: O legado teológico de Juan Luis Segundo. São Paulo: Paulinas, 1998.

CODINA, Victor. A Teologia Latino-amricana na encruzilhada. Perspectiva Teológica, Belo Horizonte, v. 14, n. 31, p. 181-200, 1999.

CODINA, Victor. Creio no Espírito Santo: Pneumatologia narrativa. São Paulo: Paulinas, 1997.

CODINA, Victor. Es posible hacer teologia hoy?. In: CODINA, Victor. Una Iglesia nazarena: Teología desde los insignificantes. Santander: Sal Terrae, 2010, p. 189203.

DUSSEL, Enrique. Filosofia da libertação. São Paulo: Loyola, 1980.

DUSSEL, Enrique. Filosofia da libertação: Crítica à ideologia da exclusão. São Paulo: Paulus, 1995.

ELLACURÍA, Ignacio. Hacia una fundamentación del método teológico latinoamericano. In: ELLACURÍA, Ignacio. Escritos Teológicos I. San Salvador: UCA, 2000a. p. 187-218.

ELLACURIA, Ignacio. El método en la teología latinoamericana. In: ELLACURÍA, Ignacio. Escritos Teológicos I. San Salvador: UCA, 200ob. p. 219-234.

ELLACURÍA, Ignacio. Historia de la salvación y salvación de la historia. In: ELLACURÍA, Ignacio. Escritos Teológicos I. San Salvador: UCA, 200oc. p. 519533.

ELLACURÍA, Ignacio. Historia de la salvación. In: ELLACURÍA, Ignacio. Escritos Teológicos I. San Salvador: UCA, 2000d. p. 597-628.

ELLACURÍA, Ignacio. Relación teoria y práxis en la teologia de la liberación. In: ELLACURÍA, Ignacio. Escritos Teológicos I. San Salvador: UCA, 2000e. p. 235245 .

ELLACURÍA, Ignacio. Tesis sobre la posibilidad, necesidad y sentido de una teologia latinoamericana. In: ELLACURÍA, Ignacio. Escritos Teológicos I. San Salvador: UCA, 2000f. p. 271-301. 
ELLACURÍA, Ignacio. La teología como momento ideológico de la praxis eclesial. In: ELLACURÍA, Ignacio. Escritos Teológicos I. San Salvador: UCA, 20oog. p. $163-185$.

ELLACURÍA, Ignacio. Escritos Filosóficos I. San Salvador: UCA, 1996.

ELLACURÍA, Ignacio. Escritos Filosóficos II. San Salvador: UCA, 1999a.

ELLACURÍA, Ignacio. Escritos Filosóficos III. San Salvador: UCA, 2001.

ELLACURÍA, Ignacio. Cursos universitários. San Salvador: UCA, 2009.

ELLACURÍA, Ignacio. Filosofia de la realidad histórica. San Salvador: UCA, $1999 b$.

ELLACURÍA, Ignacio. El aporte de la filosofia zubiriana a la teologia de la liberación. In: ELLACURÍA, Ignacio. Archivo de Ignacio Ellacuría. Caja 4, Carpeta 27. Disponível en: http://www.uca.edu.sv/centro-documentacionvirtual/wp-content/uploads/2015/03/Co4-c27-.pdf

ELLACURÍA, Ignacio; SCANNONE, Juan Carlos (compiladores). Para una filosofia desde América Latina. Bogotá: Universidad Javeriana, 1992.

FRANÇA MIRANDA, Mário de. O mistério de Deus em nossas vidas: A doutrina trinitária de Karl Rahner. São Paulo: Loyola, 1975.

GEFFRÉ, Claude. Como fazer teologia hoje: Hermenêutica teológica. São Paulo: Paulinas, 1989.

GEFFRÉ, Claude. Crer e interpretar: A virada hermenêutica da teologia. Petrópolis: Vozes, 2004.

GONZÁLEZ, Antonio. El significado filosófico de la teología de la liberación. In: COMBLIN, José; GONZÁLEZ FAUS, José Ignacio; SOBRINO, Jon. Cambio social y pensamento Cristiano en América Latina. Madrid: Trotta, 1993. p. 145-160.

GONZÁLEZ, Antonio. Estruturas de la praxis: Ensayo de una filosofía primera. Madrid: Trotta, 1997.

GONZÁLEZ, Antonio. El problema de la historia en la teologia de Gustavo Gutiérrez. Revista Latinoamericana de Teología, San Salvador, n. 18, p. 335364, 1989. 
GONZÁLEZ, Antonio, Introducción a la práctica de la filosofía. Texto de iniciación. San Salvador: UCA, 2005.

GONZÁLEZ, Antonio. La vigência del 'método teológico' en la teologia de la liberación. Sal Terrae, Madrid, n. 983, p.667-675, 1995.

GONZÁLEZ, Antonio. Surgimiento: Hacia uma ontologia de la práxis. Bogotá: USTA, 2013.

GONZÁlEZ, Antonio. Teología de la praxis evangélica: Ensayo de una teología fundamental. Santander: Sal Terrae, 1999.

GUTIÉRREZ, Gustavo. A força histórica dos pobres. Petrópolis: Vozes, 1981.

GUTIÉRREZ, Gustavo. Teologia da Libertação: Perspectivas. São Paulo: Loyola, 2000.

GUTIÉRREZ, Gustavo. Teologia e ciências sociais. In: GUTIERREZ, Gustavo. A Verdade vos libertará. São Paulo: Loyola, 2000a. p. 67-97.

GUTIÉRREZ, Gustavo. Verdade e Teologia. In: GUTIÉRREZ, Gustavo. A verdade vos libertará. São Paulo: Loyola, 200ob. p. 107-128.

GUTIÉRREZ, Gustavo. A teologia, uma função eclesial. In: GUTIÉRREZ, Gustavo. A densidade do presente. São Paulo: Loyola, 2008. p. 29-40.

IRARRAZAVAL, Diego. De baixo e de dentro: Crenças latino-americanas. São Bernardo do Campo: Nhanduti, 2007.

IRARRAZAVAL, Diego. Repercusion de lo popular en la teologia. In: COMBLIN, José; GONZÁLEZ FAUS, José Ignacio; SOBRINO, Jon. Cambio social y pensamento Cristiano en América Latina. Madrid: Trotta, 1993. p. 181-197.

JOÃO PAULO II. Carta Encíclica Fides et Ratio: sobre as relações entre fé e razão. São Paulo: Loyola, 1998.

KASPER, Walter. A misericórdia: Condição fundamental do Evangelho e chave da vida cristã. São Paulo: Loyola, 2015.

LAMPE, Armando. Ética e a filosofia da libertação: Festschrift Enrique Dussel. Petrópolis: Vozes, 1995.

LIBANIO, João Batista. Teologia da Libertação: Roteiro didático para um estudo. São Paulo: Loyola, 1987. 
MOLTMANN, Jürgen. A Igreja no poder do Espírito. Santo André: Academia Cristã, 2013.

MÜLlER, Gerhard Ludwig. Dogmática Católica: Teoria e prática da teologia. Petrópolis: Vozes, 2015.

NÉDONCELLE, Maurice. Teologia e filosofia ou as metamorfoses duma 'ancilla. Concilium, Petrópolis, n. 6, p. 69-77, 1995.

OLIVEIRA, Manfredo Araúdo de. Reviravolta linguístico-pragmática na filosofia contemporânea. São Paulo: Loyola, 1997a.

OLIVEIRA, Manfredo Araújo de. Tópicos sobre dialética. Porto Alegre: EDIPUCRS, 1997b.

OLIVEIRA, Manfredo Araújo de. Ética e racionalidade moderna. São Paulo: Loyola, 1993.

OLIVEIRA, Manfredo Araújo de. Ética e práxis histórica. São Paulo: Ática, 1995a.

OLIVEIRA, Manfredo Araújo de. Ética e economia. São Paulo: Ática, 1995b.

OLIVEIRA, Manfredo Araújo de. Diálogos entre fé e razão. São Paulo: Paulinas, 2000.

OLIVEIRA, Manfredo Araújo de. Desafios éticos da globalização. São Paulo: Paulinas, 2001.

OLIVEIRA, Manfredo Araújo de. "É necessário filosofar na teologia”: unidade e diferença entre filosofia e teologia em Karl Rahner. In: OLIVEIRA, Pedro Rubens; PAUL, Claudio. Karl Rahner em perspectiva. São Paulo: Loyola, 2004. p. 201218.

OLIVEIRA, Manfredo Araújo de. Ética, direito e democracia. São Paulo: Paulus, 2010.

OLIVEIRA, Manfredo Araújo de. A religião na sociedade urbana e pluralista. São Paulo: Paulus, 2013.

ORTIZ, S. B.; ZÚNGA, J.; GALINDO, M. S.; MELCHOR, M. A. G. La filosofia de la liberación. In: DUSSEL, Enrique; MENDIETA, Eduardo; BOHÓRQUEZ, Carmen. El pensamiento filosófico lstinosmericano, del Caribe e 'latino' (13002000): Historia, corrientes, temas y filósofos. México: Siglo XXI, 2011. p. 399-417. 
PANNENBERG, Wolfhart. Filosofia e teologia: tensões e convergências de uma busca comum. São Paulo: Paulinas, 2008.

PLATÃO. Republica. São Paulo: Martin Claret, 2000.

PRIMER ENCUENTRO MESOAMERICANO DE FILOSOFIA. Para una filosofia libertadora. San Salvador: UCA, 1995.

RAMAGLIA, Dante. La cuestión de la filosofía latinoamericana. In: DUSSEL, Enrique; MENDIETA, Eduardo; BOHÓRQUEZ, Carmen. El pensamiento filosófico lstinosmericano, del Caribe e 'latino' (1300-2000): Historia, corrientes, temas y filósofos. México: Siglo XXI, 2011. p. 377-398.

RAHNER, Karl. Curso Fundamental da Fé. São Paulo: Paulus, 1989.

RAHNER, Karl. Filosofía y teologia. In: RAHNER, Karl. Escritos de Teología VI. Madrid: Ediciones Cristiandad, 2007. p. 84-93.

RAHNER, Karl. Reflexões sobre o método da teologia. In: SANNA, Ignazio. Karl Rahner. São Paulo: Loyola, 2004. p. 71-112.

SCANNONE, Juan Carlos. A teologia da libertação: Caracterização, correntes, etapas. In: NEUFELD, Karl (Org.). Problemas e perspectivas de teologia dogmática. São Paulo: Loyola, 1993. p. 321-346.

SCANNONE, Juan Carlos. Fé cristã e filosofia hoje na América Latina. Síntese Nova Fase, Belo Horizonte, , v. 19, n. 56, p. 49-58, 1992.

SCANNONE, Juan Carlos. Nuevo punto de partida de la filosofia latinoamericana. Buenos Aires: Guadalupe, 1990.

SCANNONE, Juan Carlos. Teología de la liberación y práxis popular. Aportes críticos para una teología de la liberación. Salamanca: Sígeme, 1976.

SCANNONE, Juan Carlos. Theologie, Philosophie und Inkulturacion in Latinoamerika. In: FORNET-BETANCOURT (Hrsg.). Positionen Lateinamerikas. Frankfurt am Main: Materialis, 1989. p. 78-93.

SEGUNDO, Juan Luis. Criticas y autocriticas de la teologia de la liberación. In: COMBLIN, José; GONZÁlEZ FAUS, José Ignacio; SOBRINO, Jon. Cambio social y pensamento Cristiano en América Latina. Madrid: Trotta, 1993. p. 215-236.

SEGUNDO, Juan Luis. Libertação da Teologia. São Paulo: Loyola, 1978. 
SOBRINO, Jon. El principio-misericordia: bajar de la cruz a los pueblos crucificados. Santander: Sal Térrae, 1992. p. 47-80.

SUSIN, Luiz Carlos. O homem messiânico no pensamento de Emmanuel Levinas. Porto Alegre: EST/Vozes, 1984.

SUSIN, Luiz Carlos. O esquecimento do outro na história do Ocidente. REB, Petrópolis, n. 188, p. 820-838, 1987.

SUSIN, Luiz Carlos. Identidade como apropriação e narcisismo. Concilium, Petrópolis, n. 285, p. 90-103, 2000.

SUSIN, Luiz Carlos. Sine Propium - ontologia e antropologias em conflito: conseqüências espirituais, culturais e teológicas. Perspectiva Teológica, Belo Horizonte, v, 33, n. 91, p. 391-406, 2001.

VAZ, Henrique Claudio de Lima. Escritos de Filosofia: Problemas de Fronteira. São Paulo: Loyola, 1986.

ZIENER, Georg. Palavra. In: BAUER, Johannes. Dicionário de teologia bíblica. Volume II. São Paulo: Loyola, 1988, p. 794-798.

ZIMMERMANN, Heinrich. Conhecimento. In: BAUER, Johannes. Dicionário de teologia bíblica. Volume I. São Paulo: Loyola, 1988, p. 204-210.

ZIMMERMANN, Roque. América Latina - o Não-Ser: Uma abordagem filosófica a partir de Enrique Dussel (1962-1976). Petrópolis: Vozes, 1987.

ZUBIRI, Xavier. Inteligência e realidade. São Paulo: É Realizações, 2011a.

ZUBIRI, Xavier. Inteligência e logos. São Paulo: É Realizações, 2011b.

ZUBIRI, Xavier. Inteligência e razão. São Paulo: É Realizações, 2011c. 